\title{
TOLERANCE AND REVERSE TOLERANCE TO HALOPERIDOL CATALEPSY INDUCED BY THE DIFFERENCE OF ADMINISTRATION INTERVAL IN MICE
}

\author{
Yoshikatsu MASUDA, Shigeo MURAI and Tadanobu ITOH \\ Department of Pharmacology. School of Dentistry. \\ Iwate Medical College. Morioka 020. Japan
}

Accepted July 24, 1982

\begin{abstract}
Although it is known that haloperidol (HP) induces catalepsy in animals, there is disagreement among various authors as to whether tolerance develops (1-3) or not (4-6) by repeated administration of this drug. In order to elucidate these conflicting results, the present study was carried out by repeated administration of various doses of $\mathrm{HP}$ at different intervals.

The cataleptic action of HP was tested on ninety ddY strain male mice (initially weighing 20-22 g). The animals were housed in the colony cage at a constant temperature of $24 \pm 1{ }^{\circ} \mathrm{C}$ under a $12 \mathrm{hr}$ light/dark cycle and allowed free access to mouse biscuits (Oriental Yeast Co.) and water at all times. HP (Shionogi Seiyaku) was dissolved at the concentration of $1 \mathrm{mg} / 1 \mathrm{ml}$ of $0.1 \mathrm{M}$ trataric acid and further diluted with a saline solution for administering as an aqueous solution in a volume of $0.1 \mathrm{ml}$ per $10 \mathrm{~g}$ mouse. HP at $0.075,0.3,0.6,1.2$ and $4.8 \mathrm{mg} / \mathrm{kg}$ were orally administered at three different intervals: daily (successive administration), every 2 and 4 days (intermittent administration), and at about 10 a.m. for 21 days. Each group consisted of 6 mice. Catalepsy was evaluated $3 \mathrm{hr}$ after administration of HP. The duration of the unnatural posture that a mouse showed when his left forepaw was placed on a horizontal bar (1.2 $\mathrm{mm}$ diameter) which was suspended $1.3 \mathrm{~cm}$ above a platform was measured to evaluate the intensity of HP
\end{abstract}

catalepsy. The left forepaw was placed on the bar four times, the maximum allowable duration for each trial being $300 \mathrm{sec}$. The maximum duration among 4 trials was recorded. The statistical significance of differences in the results was calculated according to the Student's $t$-test.

In repeated administration of $\mathrm{HP}$ at 0.075 and $0.3 \mathrm{mg} / \mathrm{kg}$. no modification of the bar time (i.e., the duration of unnatural posture) was observed for any of the administration intervals (Fig. 1, upper panel). In the case of $0.6 \mathrm{mg} / \mathrm{kg} \mathrm{HP}$, the value of the bar time did not change during the period of experiment with the successive administration, but it increased in response to the number of administrations with the intermittent administration. The bar time on the 21 st day, $146 \pm 16$ sec for the 2 day interval and $215 \pm 57 \mathrm{sec}$ for the 4 day interval, significantly increased in comparison with those on the first day of the experiment, $60 \pm 7 \mathrm{sec}$ and $73 \pm 9 \mathrm{sec}$, respectively (Fig. 1, middle panel). In the case of repeated administration of $\mathrm{HP}$ at 1.2 and $4.8 \mathrm{mg} / \mathrm{kg}$, the bar time showed a biphasic time course with the successive administration (Fig. 1. lower panel). Namely, the bar time clearly decreased within 2-3 days after HP treatment, then showed a tendency to recover from these decrements. but even on the 21 st day, did not return up to the initial level $(P<0.05)$. On the other hand, the bar time increased in response to 

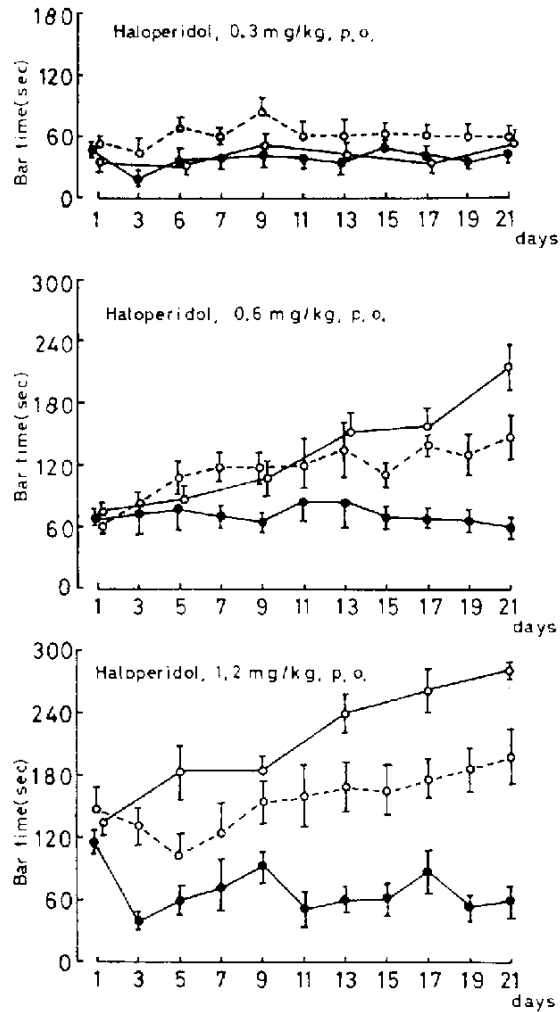

Fig. 1. The time courses in the modification of cataleptic action induced by repeated administration of haloperidol. The ordinate indicates the duration of unnatural posture measured to evaluate the intensity of cataleptic action. Each point is the average bar time for 6 mice measured 3 hours after the administration of haloperidol. Bars are the S.E.M. The mice received haloperidol orally for 21 days at the following administration intervals: - daily. $O \quad O$ : every 2 days. o-O O every 4 days.

the number of administrations with the intermittent administration of HP at 1.2 and $4.8 \mathrm{mg} / \mathrm{kg}$. This tendency was clearer when HP was administered every 4 days than every 2 days

Figure 2 shows the comparison of the dose response curve of cataleptic action on the 21 st day of repeated administration with that on the first day. The modification of cataleptic action caused by the repeated administration was recognized not at doses of HP at 0.075 and $0.3 \mathrm{mg} / \mathrm{kg}$, but at doses of

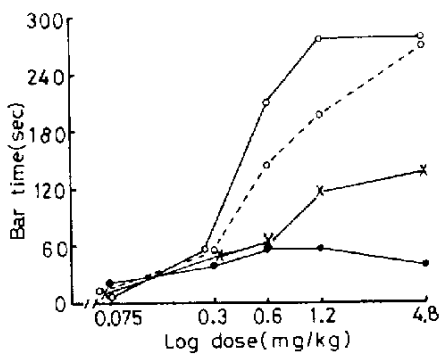

Fig. 2. Dose-response curves to haloperidol catalepsy measured after a single administration $(x-x)$ and on the 21 st day of repeated administration (O-Oaily, $O \cdots \cdots$ : every 2 days, O- every 4 days

$\mathrm{HP}$ at $0.6,1.2$ and $4.8 \mathrm{mg} / \mathrm{kg}$. The mode of the modification to HP catalepsy varied with the administration intervals, that is, a tolerance developed with the successive administration, whereas a reverse tolerance developed with the intermittent administration.

As reason for the disagreement between former results and ours concerning tolerance to HP catalepsy judging from the results of this experiment, it is conceivable that in the former reports, not enough consideration was given to the doses or the administration interval in addition to the difference of the experimental method. In this experiment, it was noted that when HP was administered repeatedly at doses above $0.6 \mathrm{mg} / \mathrm{kg}$, the intensity of cataleptic action decreased in the successive administration; on the contrary, it increased in the intermittent administration. Phenomena similar to the latter have been reported in the accelerating effect on ambulatory activity of cocaine in rats and amphetamine in mice $(7,8)$ and the inhibitory effect of HP on avoidance response in rats (9): but repoits as observed in this experiment, an effect of drug divided into two tendencies (tolerance and reverse tolerance) according to the difference in the administration interval. have not been published to date. The major mechanism of action of neuroleptics in the production of catalepsy 
has been assumed to be blockade of postsynaptic doparminergic receptor sites (10). Some workers showed that when mice were treated with neuroleptics, an initial period of receptor blockade was replaced by receptor supersensitivity within a few days $(11,12)$. The mechanism of the phenomena observed in this experiment is unknown, but it can be considered that the supersensitivity phase which appears after withdrawal of HP may participate in the reverse tolerance produced by the intermittent administration.

\section{REFERENCES}

1) Asper, H., Baggiolini, M., Burki, H.R., Lauener,

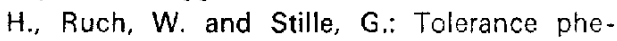
nomena with neuroleptics catalepsy, apomorphine stereotypies and striatal dopamine metabolism in the rat after single and repeated administration of loxapine and haloperidol. Eur. J. Pharmacol. 22, 287-294 (1973)

2) Gessa, G.L. and Tagliamonte, A.: Effect of methadone and dextromoramide on dopamine metabolism. Comparison with haloperidol and amphetamine. Neuropharmacology 14, 913920 (1975)

3) Ezrin-Waters, C. and Seeman, P.: Tolerance to haloperidol catalepsy. Eur. J. Pharmacol. 41, 321-327 (1977)

4) György, L., Pfeifer, K.A. and Hajtman, B.: Modification of certain central nervous effects of haloperidol during long-term treatment in the mouse and rat. Psychopharmacologia (Berlin) 16, 223-233 (1969)

5) Nielsen, I.M., Fjalland, B., Pedersen, V. and Nymark, M.: Pharmacology of neuroleptics upon repeated administration. Psychopharmacologia (Berlin) 34, 95-104 (1974)

6) Puri, S.K. and Lal, H.: Tolerance to the behavioral and neurochemical effects of haloperidol and morphine in rats chronically treated with morphine or haloperidol. Naunyn Schmiedebergs Arch. Pharmacol. 282, 155170 (1974)

7) Post, R.M, and Rose, H.: Increasing effects of repetitive cocaine administration in the rat. Nature 260, 731-732 (1976)

8) Ohashi, K. and Tadokoro, S.: Effects of thyroidectomy on amphetamine-induced acceleration of locomotor activity in mice. Japan. J. Pharmacol. 26, 621-624 (1976)

9) Hayashi, T. and Tadokoro, S.: Effect of drug changed by repeated administration, and environment. Seibutsu Kagaku 32, 75-82 (1980) (in Japanese)

10) Sanberg, P.R.: Haloperidol-induced catalepsy is mediated by postsynaptic dopamine receptor. Nature 284, 472-473 (1980)

11) Vonvoigtlander, P.F., Losey, E.G. and Triezenberg, H.J.: Increased sensitivity to dopaminergic agents after chronic neuroleptic treatment. J. Pharmacol. Exp. Ther. 193, 88-94 (1975)

12) Nielsen, I.M. and Christensen, A.V.: Long term effect of neuroleptic drug. J. Pharmacol. 6 , $277-282(1975)$ 